\title{
Analisis Variabel Yang Mempengaruhi Harga Saham Syariah di Jakarta Islamic Index
}

\author{
Lisa Febriani \\ Fakultas Ekonomi dan Bisnis, Universitas Airlangga, Surabaya \\ Email: lisafebriani@gmail.com
}

\begin{abstract}
Abstrak: One of the methods used by companies to obtain company capital is by selling shares to the public through the capital market. Stock prices can change and this is changed by various factors. This study aims to determine the effect of Debt to Equity Ratio (DER), Earning per Share (EPS), and Return on Equity (ROE) on sharia stock prices listed in the Jakarta Islamic Index (JII) in 2014-2017, both partially and simultaneously. The data used in this study is secondary data taken from the Indonesia Stock Exchange website (www.idx.co.id), which is in the form of a company's annual financial report. The analysis technique used in this study uses Linear Regression Analysis. Based on the research results, it is known that partially DER has no significant effect on stock prices, while EPS and ROE have a significant effect on stock prices. Simultaneously, DER, EPS, and ROE significantly influence stock prices.
\end{abstract}

Kata kunci: Harga saham, Debt to Equity Ratio (DER), Earning per Share (EPS), Return on Equity (ROE).

\section{PENDAHULUAN}

Pasar modal merupakan salah satu sarana pembiayaan jangka panjang bagi perusahaan dan alternative investasi bagi investor. Salah satu cara yang digunakan oleh perusahaan untuk memperoleh modal perusahaan adalah dengan menjual saham kepada public melalui pasar modal. Keuntungan yang diperoleh investor dari investasi saham dapat berupa capital gain dan/atau dividen. Namun, keuntungan tersebut juga diiringi dengan risiko ketidakpastian pergerakan (fluktuasi) harga saham yang dapat mengakibatkan kerugian yang diderita oleh investor. Fluktuasi harga saham ini dapat disebabkan oleh beberapa factor.

Harga saham juga mengikuti hukum permintaan dan penawaran (supply and demand theory). Harga saham ditentukan oleh jumlah penawaran dan permintaan akan saham itu sendiri. Semakin banyak pihak yang melakukan permintaan atau pembelian terhadap suatu saham, maka harga saham tersebut cenderung merangkak naik dan sebaliknya. Semakin banyak pihak yang melakukan penawaran atau penjualan suatu saham, maka harga saham tersebut akan cenderung menurun.

(Samsul, 2011) menyatakan bahwa terdapat variabel-variabel yang memengaruhi harga saham, antara lain variabel makroekonomi, variabel makro non ekonomi, dan variabel mikroekonomi. Variabel makroekonomi terinci dalam variable ekonomi, seperti inflasi, suku bunga, kurs valuta asing, tingkat pertumbuhan ekonomi, harga bahan bakar minyak di pasar internasional, dan indeks harga saham regional. Selanjutnya, peristiwa politik 
domestic, peristiwa social, peristiwa hukum, dan peristiwa politik internasional merupakan variabel makro non ekonomi yang memengaruhi harga saham perusahaan. Sedangkan variabel mikroekonomi berupa laba per saham atau Earning per Share (EPS), dividen per saham atau Dividend per Share (DPS), nilai buku per tahun, rasio utang terhadap ekuitas atau Debt to Equity Ratio (DER), dan rasio keuangan lainnya.

Dengan banyaknya variabel-variabel yang dapat mempengaruhi naik turunnya harga saham, maka investor harus memiliki informasi yang akurat, lengkap, dan up to date untuk menghindari atau mengurangi risiko berinvestasi saham di pasar modal. Salah satu sumber informasi yang dapat digunakan investor dalam pengambilan keputusan adalah laporan keuangan. Dengan melihat laporan keuangan perusahaan, investor dapat menganalisa kinerja perusahaan yang tercermin dari rasio-rasio keuangan sebagai salah satu pertimbangan untuk menaksir imbal hasil (return) yang akan diperolehnya.

Dalam penelitian ini, beberapa rasio keuangan yang berhubungan dengan kinerja keuangan perusahaan, antara lain Debt to Equity Ratio (DER), Earning per Share (EPS), dan Return on Equity (ROE). (Darsono dan Ashari, 2005) menjelaskan definisi Debt to Equity Ratio (DER) sebagai rasio keuangan yang menunjukkan sanggup atau tidaknya suatu perusahaan dalam membayar kewajiban jangka panjangnya. Sedangkan Earning per Share (EPS) didefinisikan oleh (Darsono dan Ashari, 2005) sebagai rasio keuangan yang menggambarkan besarnya pengembalian modal untuk setiap satu lembar saham. Return on Equity (ROE) merupakan rasio keuangan yang digunakan untuk menilai besarnya pengembalian yang dapat diberikan oleh suatu perusahaan atas setiap modal yang telah ditanamkan oleh pemilik atau investor di perusahaan tersebut (Darsono dan Ashari, 2005).

Di Indonesia, indeks saham syariah yang pertama kali diluncurkan adalah Jakarta Islamic Index (JII). Indeks ini diluncurkan di pasar modal Indonesia pada 3 Juli 2000. Saham-saham yang terdaftar di dalam JII dinilai berdasarkan prinsip syariah. Emiten yang masuk ke dalam JII harus sesuai dengan aturan yang diatur oleh Dewan Syariah Nasional Majelis Ulama Indonesia (DSN MUI). Kriteria tersebut diatur dalam Pasal 3 Fatwa DSNMUI No: 40/DSN-MUI/X/2003 tentang Pasar Modal dan Pedoman Umum Penerapan Prinsip Syariah di Bidang Pasar Modal, antara lain: (1) Jenis atau macam usaha, produk barang dan/atau jasa yang diberikan, akad serta cara pengelolaan perusahaan yang mengeluarkan atau menerbitkan efek syariah tidak diperkenankan berlawanan dengan prinsip-prinsip syariah. (2) Jenis atau macam kegiatan usaha yang berlawanan dengan prinsip-prinsip syariah, antara lain: Kegiatan usaha yang terkait dengan perjudian atau perdagangan yang dilarang; Lembaga keuangan konvensional atau yang berkaitan dengan hal-hal ribawi, contohnya perbankan dan asuransi konvensional; Produsen, distributor, serta pedagang makanan dan minuman yang mengandung zat-zat yang haram; Produsen, distributor, dan/atau penyedia barang-barang ataupun jasa yang dapat merusak moral dan bersifat mudara; dan Melakukan penanaman modal atau investasi pada perusahaan yang pada saat transaksi tingkat (nisbah) utangnya kepada lembaga keuangan konvensional atau ribawi lebih dominan daripada modal perusahaan itu sendiri. (3) Perusahaan public yang hendak mengeluarkan atau menerbitkan efek syariah disyaratkan untuk menandatangani dan memenuhi ketentuan akad yang sesuai dengan syariah atas efek syariah yang dikeluarkan/diterbitkan. (4) Perusahaan public yang hendak mengeluarkan atau menerbitkan efek syariah harus menjamin bahwa kegiatan usahanya memenuhi prinsipprinsip syariah dan memiliki Shariah Compliance Officer. (5) Dalam hal perusahaan public yang mengeluarkan atau menerbitkan efek syariah sewaktu-waktu tidak memenuhi 
persyaratan tersebut di atas, maka efek yang diterbitkan dengan sendirinya sudah bukan lagi sebagai efek syariah.

Sampai dengan 26 Desember 2018, sudah terdapat 407 (empat ratus tujuh) saham yang masuk dalam penghitungan Indeks Saham Syariah Indonesia (ISSI).

Melihat rasio DER, EPS, dan ROE masih menjadi rasio keuangan yang sering dianalisis oleh para investor saham dan semakin berkembangnya pasar modal syariah di Indonesia, maka peneliti tertarik untuk menganalisis variable-variabel tersebut dalam penelitian "Analisis Variabel yang Memengaruhi Harga Saham di Jakarta Islamic Index".

\section{KAJIAN TEORI}

Beberapa penelitian telah mencoba menganalisis berbagai faktor-faktor yang mempengaruhi harga saham. (Amanda, 2013) menganalisis pengaruh empat rasio keuangan terhadap harga saham. Raiso-rasio keuangan tersebut adalah DER, ROE, EPS, dan PER. Hasil penelitian menunjukkan bahwa variabel DER, ROE, EPS, dan PER secara bersamasama (simultan) memberikan pengaruh yang signifikan terhadap harga saham, yaitu sebesar $64,6 \%$, sedangkan sisanya, yaitu sebesar 35,4\% dipengaruhi oleh variabel lain yang tidak digunakan dalam penelitian. Secara parsial, variabel DER, ROE, dan EPS memiliki pengaruh yang signifikan terhadap harga saham. DER memiliki pengaruh negatif terhadap harga saham, sedangkan variabel ROE dan EPS memiliki pengaruh positif terhadap harga saham. Sementara variabel PER tidak memiliki pengaruh terhadap harga saham.

(Ratih dkk., 2013) melakukan penelitian untuk melihat pengaruh 4 (empat) rasio keuangan terhadap harga saham di sektor pertambangan yang terdaftar di Bursa Efek Indonesia (BEI). Empat rasio keuangan tersebut adalah Earning per Share (EPS), Price to Earning Ratio (PER), Debt to Equity Ratio (DER), dan Return on Equity (ROE). Dalam penelitian ini digunakan data sekunder yang diperoleh dari BEI pada periode 2010-2012. Hasil penelitian ini menunjukkan bahwa secara parsial, rasio EPS, PER, dan ROE memiliki efek yang positif dan signifikan terhadap harga saham. Artinya, apabila rasio EPS, PER dan ROE naik, maka harga saham juga ikut menanjak. Sedangkan rasio utang terhadap ekuitas (DER) memiliki pengaruh negatif terhadap harga saham. Artinya, apabila rasio DER tinggi, maka harga saham akan bergerak ke arah sebaliknya (menurun). Rasio EPS memiliki pengaruh yang paling kuat terhadap harga saham. Secara bersama-sama (simultan) keempat rasio keuangan tersebut (EPS, PER, DER, dan ROE) memiliki pengaruh yang signifikan terhadap harga saham.

Penelitian serupa juga dilakukan oleh (Husna, 2016). Penelitiannya mencoba menguji pengaruh rasio-rasio keuangan terhadap harga saham perusahaan perbankan yang terdaftar di BEI pada periode 2011-2014. Variabel dependen pada penelitian ini adalah rasio tingkat pengembalian asset atau Return on Asset (ROA), rasio harga saham terhadap pendapatan perusahaan atau Price to Earning Ratio (PER), dan laba per saham atau Earning per Share (EPS). Hasil penelitian menyimpulkan bahwa variabel PER dan EPS memiliki dampak yang positif dan signifikan terhadap harga saham, sedangkan variabel ROA dan DER tidak berpengaruh signifikan terhadap harga saham perusahaan perbankan yang sahamnya terdaftar di BEI pada 2011-2014. 
(Nahariyah dan Apriatni, 2017) menganalisis pengaruh variabel Current Ratio (CR), Debt to Equity Ratio (DER), Return On Asset (ROA), Return On Equity (ROE), dan Earning Per Share (EPS) terhadap naik turunnya harga saham perusahaan sub sektor konstruksi bangunan yang terdaftar di Bursa Efek Indonesia periode 2011-2015. Hasil penelitian menyimpulkan bahwa secara parsial maupun simultan terdapat pengaruh yang signifikan dari kelima variabel rasio keuangan (CR, DER, ROA, ROE dan EPS) terhadap naik turunnya harga saham perusahaan sub sector konstruksi bangunan yang terdaftar di BEI pada periode 2011-2015. Variabel yang memberikan pengaruh paling kuat terhadap naik turunnya harga saham dalam penelitian ini adalah rasio EPS.

Penelitian lain dilakukan oleh (Hudaya dan Pustikaningsih, 2017) yang ingin menguji bagaimana pengaruh rasio utang atas ekuitas atau Debt to Equity Ratio (DER), rasio laba atas ekuitas atau Return on Equity (ROE), dan rasio laba bersih atas pendapatan perusahaan atau Net Profit Margin (NPM) terhadap harga saham perusahaan pertambangan yang terdaftar di BEI periode 2011-2015 baik secara parsial maupun simultan. Hasil penelitian menunjukkan bahwa secara parsial variabel DER, ROE, dan NPM berpengaruh signifikan terhadap harga saham perusahaan pertambangan yang terdaftar di BEI periode 2011-2015. ROE dan NPM berpengaruh signifikan positif terhadap harga saham. Artinya, harga saham akan naik apabila rasio ROE dan NPM perusahaan meningkat. Sedangkan DER berpengaruh signifikan negative terhadap harga saham perusahaan pertambangan yang terdaftar di BEI periode 2011-2015. Artinya, arah pergerakan DER berkebalikan dengan arah pergerakan harga saham. Semakin tinggi DER, maka akan semakin rendah harga saham, begitu pula sebaliknya. Secara simultan, ketiga variabel tersebut (DER, ROE, dan NPM) berpengaruh signifikan terhadap naik turunnya harga saham perusahaan pertambangan yang terdaftar di BEI periode 2011-2015.

(Widya dan Abundanti, 2018) melakukan penelitian terhadap 12 (dua belas) perusahaan otomotif dan komponen yang terdaftar di Bursa Efek Indonesia (BEI) periode 2012-2016. Dalam penelitian ini diuji tingkat signifikasi dan pengaruh variabel EPS, PER, $\mathrm{CR}$, dan ROE terhadap pergerakan harga saham. Hasil penelitian menunjukkan bahwa keempat rasio keuangan dalam penelitian ini (EPS, PER, CR, dan ROE) secara bersamasama (simultan) berpengaruh signifikan terhadap pergerakan harga saham. Secara parsial, PER berpengaruh positif signifikan terhadap harga saham. Hal ini menandakan bahwa investor sebaiknya memperhatikan variabel PER ketika akan membeli saham karena semakin tinggi PER, semakin tinggi juga harga saham. Sedangkan variabel EPS, CR, dan ROE berpengaruh signifikan dan negative terhadap harga saham. Artinya, semakin tinggi EPS, CR dan ROE, maka akan semakin rendah harga sahamnya.

(Christian dan Frecky, 2019) juga melakukan penelitian yang meneliti faktor-faktor yang mempengaruhi harga saham 121 (seratus dua puluh satu) perusahaan yang terdaftar di Bursa Efek Indonesia pada periode 2012-2016. Variabel dependen yang dianalisis dalam penelitian ini ada 7 (tujuh), yaitu ROE, nilai buku per saham, laba per saham, dividen per saham, hasil dividen, PER, dan rasio utang terhadap total asset. Variabel kontrolnya adalah ukuran perusahaan. Hasil penelitian menyatakan bahwa ROE, nilai buku per saham, EPS, DPS, dan ukuran perusahaan memiliki pengaruh yang signifikan dan positif terhadap naik turunnya harga saham, sedangkan hasil dividen memiliki pengaruh yang signifikan dan negative terhadap harga saham. Hasil yang lain dari penelitian ini menunjukkan bahwa PER dan rasio utang terhadap total aktiva memiliki pengaruh yang tidak signifikan terhadap 
pergerakan harga saham 121 (seratus dua puluh satu) perusahaan yang terdaftar di Bursa Efek Indonesia pada periode 2012-2016.

Penelitian lain dilakukan oleh (Haryanti dan Murtiasih, 2019) yang ingin mengetahui pengaruh rasio keuangan terhadap harga saham dengan EPS sebagai variabel moderasi. Dalam penelitian ini, variabel yang digunakan untuk menggambarkan rasio keuangan adalah Debt to Equity Ratio (DER), Return on Asset (ROA), Dividend Payout Ratio (DPR) dan Earning Per Share (EPS). Data yang digunakan dalam penelitian ini adalah data sekunder di BEI dan laporan tahunan perusahaan. Populasi yang digunakan dalam penelitian ini adalah perusahaan perbankan yang terdaftar di BEI pada periode 2009-2018 dan merupakan bank milik negara (BUMN). Hasil penelitian menunjukkan bahwa DER, ROA dan EPS secara parsial mempengaruhi harga saham, sedangkan DPR tidak mempengaruhi harga saham. Secara bersamaan, DER, ROA dan DPR mempengaruhi harga saham. Uji pada variabel moderasi dalam penelitian ini menunjukkan bahwa semakin tinggi EPS, semakin kuat efek ROA dan DPR terhadap harga saham. Dalam penelitian ini, EPS terbukti tidak mampu memoderasi DER secara parsial dan tidak mampu memoderasi DER, ROA, dan DPR secara bersamaan.

Beberapa peneliti di luar negeri juga mencoba menganalisis faktor-faktor yang mempengaruhi harga saham. Seperti penelitian di Nigeria oleh (Ernest dan Oscar, 2014) yang meneliti tentang faktor yang mempengaruhi harga saham di perusahaan yang bergerak di sektor perbankan dan perminyakan. Hasilnya menunjukkan jika book value per share, leverage, earning per share memiliki pengaruh terhadap harga saham di perusahaan yang bergerak di sektor perbankan dan perminyakan.

(Islam et al., 2014) ingin mengetahui bagaimana Earning Per Share (EPS) memengaruhi harga saham dan nilai perusahaan. Telah dikumpulkan dan dianalisis 22 bank dalam 110 data tahun perusahaan dan menemukan bahwa harga saham tidak bergerak secepat sebagaimana pergerakan EPS. Hasil penelitian juga menemukan bahwa pergerakan harga saham tergantung pada faktor ekonomi mikro dan makro pada ekonomi.

(Inyiama, 2015) melakukan penelitian di Nigeria dari tahun 2004 hingga 2013. Pada penelitian ini earning per share memiliki pengaruh yang signifikan terhadap harga saham terutama di perusahaan-perusahaan yang bergerak di jasa perbankan. Selain itu, (Rauf, 2015) melakukan identifikasi terhadap faktor-faktor yang mempengaruhi harga saham perusahaan-perusahaan yang bergerak di bidang perbankan di Colombo. Penelitian ini menjelaskan bahwa yang menjadi faktor dalam harga saham diantaranya adalah dividend per share, book value per share, dividend payout, earning per share, price earnings dan firm size.

Penelitian lain dilakukan oleh (Issah dan Mohammed, 2015) yang menyelidiki secara empiris apakah ROA, ROE, dan ROI bersama-sama memengaruhi pergerakan harga pasar per saham yang diperdagangkan oleh perusahaan public di bidang perbankan di Ghana untuk periode 2009 - 2013. Hasil penelitian menemukan hubungan linier yang signifikan antara ROA, ROE, dan ROI bersama-sama harga pasar per saham, dengan ROE berkontribusi lebih dari ROA. Temuan ini konsisten dengan literatur empiris dan teoritis yang mengandaikan hubungan linier positif. Temuan ini memiliki implikasi penting bagi investor, manajemen senior bank, dan regulator bank untuk meningkatkan kualitas pelaporan yang dikutip oleh bank di bursa.

(Al Qaisi et al., 2016) juga melakukan penelitian mengenai factor-faktor yang memengaruhi harga saham. Penelitian ini bertujuan untuk mengetahui pengaruh beberapa 
faktor terhadap harga saham pasar seperti Return on Asset (ROA), Return on Equity (ROE), rasio utang, usia perusahaan, dan ukuran perusahaan. Untuk mencapai tujuan tersebut, penelitian ini menggunakan 20 (dua puluh) perusahaan asuransi yang terdaftar di bursa saham Amman selama periode 2011 hingga 2015. Analisis data mencakup regresi liner sederhana dan berganda dan hasilnya menemukan bahwa ada pengaruh antara (ROA, rasio utang, usia perusahaan, dan ukuran perusahaan) dan harga pasar saham di perusahaan asuransi yang terdaftar di bursa efek Amman. Selain itu, hasil menemukan bahwa tidak ada pengaruh antara ROE dan harga saham pasar di perusahaan asuransi ini.

Penelitian yang mirip juga dilakukan oleh (Kumar, 2017). Ia meneliti dampak penghasilan per saham (Earning Per Share atau EPS) dan dan Price to Earnings Ratio (PER) terhadap harga pasar saham pada sektor otomotif di India. Studi ini dilakukan untuk sampel delapan perusahaan mobil sektor berdasarkan indeks otomatis Nifty dan untuk periode lima tahun keuangan berturut-turut dari 2011 hingga 2015. Analisis regresi berganda digunakan untuk memprediksi dampak pendapatan per saham dan rasio pendapatan harga terhadap harga pasar saham perusahaan-perusahaan tertentu di sektor otomotif. Hasil penelitian ini menyimpulkan bahwa laba per saham telah ditemukan sebagai peramal yang sangat kuat dari harga pasar saham, sementara rasio harga pendapatan berdampak signifikan pada prediksi harga pasar saham perusahaan-perusahaan tertentu di sektor otomotif secara keseluruhan.

(Antono et al., 2019) meneliti apakah harga saham perusahaan pertambangan dipengaruhi oleh beberapa faktor, seperti harga minyak dunia, inflasi, nilai tukar, dan Price to Earnings Ratio (PER), urusan politik, harga logam dasar, dan lain-lain. Tujuan dari penelitian ini adalah untuk menganalisis pengaruh beberapa faktor yang mempengaruhi harga saham perusahaan pertambangan termasuk Price to Earnings Ratio (PER), harga minyak dunia, inflasi, dan nilai tukar. Data sekunder dari Laporan Tahunan Bursa Efek Indonesia (BEI), Energy Information Administration (EIA), dan Bank Indonesia digunakan sebagai sumber analisis data. Tiga puluh lima perusahaan pertambangan dipilih sebagai sampel dari empat sub-sektor pertambangan, yaitu batubara, minyak dan gas, logam dan mineral lainnya, dan batu. Hasilnya dianalisis dengan menggunakan model analisis regresi data panel melalui penerapan EVIEWS 10 (Wahyu, 2009). Hasilnya menunjukkan bahwa Price to Earnings Ratio (PER) dan harga minyak dunia berpengaruh positif dan signifikan terhadap pergerakan harga saham. Inflasi memiliki pengaruh yang negative dan signifikan terhadap pergerakan harga saham sedangkan nilai tukar tidak berpengaruh signifikan terhadap pergerakan harga saham.

\section{Hipotesis}

Berdasarkan penjelasan di atas, maka hipotesis sementara dari penelitian ini adalah:

$\mathbf{H}_{1}$ : DER secara parsial memiliki pengaruh yang signifikan terhadap pergerakan harga saham

H2: EPS secara parsial memiliki pengaruh yang signifikan terhadap pergerakan harga saham

H3: ROE secara parsial memiliki pengaruh yang signifikan terhadap pergerakan harga saham

H4: DER, EPS, dan ROE secara simultan memiliki pengaruh yang signifikan terhadap pergerakan harga saham 


\section{METODOLOGI}

Jenis penelitian yang digunakan dalam penelitian ini adalah tipe eksplanasi (explanatory research), yaitu penelitian yang bertujuan untuk menjelaskan hubungan kausal antara variabel-variabel melalui pengujian hipotesis (Hasan, 2008).

Populasi pada penelitian ini adalah semua perusahaan yang terdaftar dalam Jakarta Islamic Index (JII) pada tahun 2014-2017 yang berjumlah 44 (empat puluh empat) perusahaan. Konstituen JII hanya terdiri dari 30 (tiga puluh) saham syariah paling likuid yang tercatat di Bursa Efek Indonesia (BEI). Adapun kriteria likuiditas yang digunakan dalam menyeleksi 30 (tiga puluh) saham syariah yang menjadi konstituen JII adalah sebagai berikut: (1) Saham syariah yang masuk dalam daftar Indeks Saham Syariah Indonesia (ISSI) dan telah tercatat selama 6 (enam) bulan terakhir. (2) Dipilih 60 (enam puluh) saham berdasarkan urutan rata-rata kapitalisasi pasar tertinggi selama 1 tahun terakhir. (3) Dari 60 (enam puluh) saham tersebut, kemudian dipilih 30 (tiga puluh) saham berdasarkan rata-rata nilai transaksi harian di pasar regular tertinggi.

Prosedur pengambilan sampel penelitian menggunakan metode purposive sampling dengan kriteria sampel yang akan digunakan adalah perusahaan yang terdaftar dalam JII pada 2014-2017 yang menyediakan laporan keuangan secara lengkap selama tahun 20142017. Dari 44 (empat puluh empat) perusahaan yang menjadi populasi, hanya 16 (enam belas) perusahaan yang memenuhi criteria menjadi sampel penelitian.

Data-data yang diperoleh dalam penelitian ini diuji menggunakan analisis regresi sederhana dan analisis regresi berganda dengan aplikasi Eviews. Namun, sebelum dilakukan pengujian regresi terhadap hipotesis penelitian, data terlebih dahulu dilakukan pengujian asumsi klasik yang meliputi uji normalitas, multikolinieritas, heteroskedastisitas, dan autokorelasi. Dalam penggunaan regresi berganda, pengujian hipotesis harus menghindari adanya kemungkinan penyimpangan asumsi-asumsi klasik. Tujuan pemenuhan asumsi klasik ini agar variabel independen sebagai estimator atas variabel dependen tidak mengalami bias.

Variabel penelitian yang digunakan dalam penelitian ini terdiri dari 3 variabel independen (X1), (X2) dan (X3) dan satu jenis variabel dependen (Y). Variabel dependen (Y) dalam penelitian ini adalah harga saham sedangkan variabel independen adalah Debt to Equity Ratio (DER) sebagai X1, Earning per Share (EPS) sebagai X2, dan Return on Equity (ROE) sebagai X3.

\section{HASIL DAN PEMBAHASAN}

Uji Normalitas. Uji normalitas adalah proses statistik yang digunakan untuk menentukan apakah sampel atau kelompok data apa pun cocok dengan distribusi normal standar. Uji normalitas dapat dilakukan secara matematis dan grafis. Dalam pembahasan ini akan digunakan Uji Jarque Bera, yaitu salah satu uji normalitas untuk mengetahui apakah skewness dan kurtosis sampel sesuai dengan distribusi normal. Data dinyatakan berdistribusi normal jika Nilai Probability (P Value) lebih besar dari 5\% atau 0,05. 
Gambar 1. Hasil Uji Normalitas dengan Jarque Bera
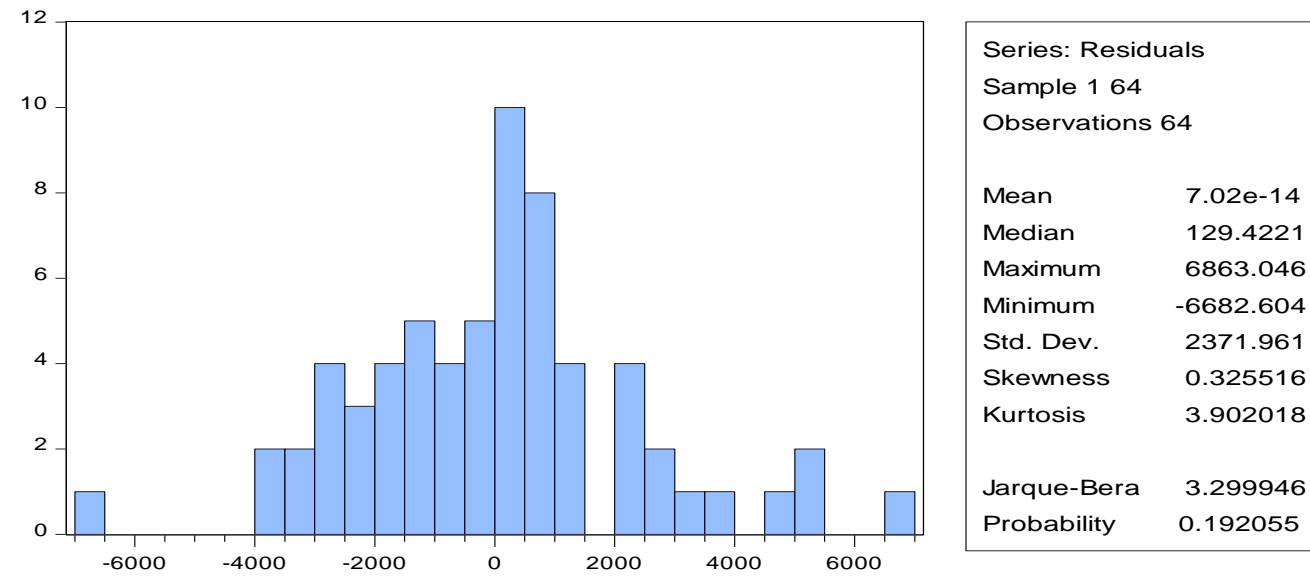

Sumber: (Output Eviews, 2019)

Gambar diatas menggunakan model Jaque-Bera yang menunjukkan Nilai Probabilitas (P Value) sebesar 0,192055. Nilai tersebut lebih besar dari 0,05 sehingga dapat disimpulkan bahwa residual berdistribusi normal.

Uji Multikolinearitas. Menurut (Priyatno, 2008) uji multikolinearitas digunakan untuk mengetahui ada atau tidaknya penyimpangan asumsi klasik multikolinearitas, yaitu adanya hubungan linear antar variabel independen dalam model regresi.

Multikolinieritas adalah keadaan interkorelasi yang sangat tinggi atau antar asosiasi di antara variabel independen. Hal ini merupakan jenis gangguan pada data, dan jika ada dalam data, kesimpulan statistik yang dibuat tentang data mungkin tidak dapat diandalkan. Derajat multikolinearitas yang tinggi akan mengakibatkan tingginya ketidaktepatan koefisien-koefisien regresi. Multikolinearitas salah satunya dapat dideteksi dengan nilai centered variance inflation factor (VIF). Jika nilai centered VIF lebih dari atau sama dengan 10, maka multikolinearitas bermasalah. 
Tabel 1. Hasil Uji Multikolinearitas

Variance Inflation Factors

Date: 01/11/20 Time: 22:50

Sample: 164

Included observations: 64

\begin{tabular}{|c|c|c|c|}
\hline Variable & $\begin{array}{c}\text { Coefficient } \\
\text { Variance }\end{array}$ & $\begin{array}{c}\text { Uncentered } \\
\text { VIF }\end{array}$ & $\begin{array}{c}\text { Centered } \\
\text { VIF }\end{array}$ \\
\hline $\mathrm{C}$ & 422692.1 & 4.579306 & NA \\
\hline DER & 379038.4 & 5.394809 & 1.557215 \\
\hline EPS & 0.812789 & 2.214014 & 1.174740 \\
\hline ROE & 198.3214 & 2.731169 & 1.750895 \\
\hline
\end{tabular}

Sumber: (Output Eviews, 2020)

Dari tabel diatas dapat diketahui bahwa nilai Centered VIF masing-masing sebesar 1,557215, 1,174740, dan 1.750895. Ketiganya memiliki nilai kurang dari 10 sehingga dapat dinyatakan bahwa tidak terdapat masalah multikolinearitas di dalam model prediksi.

Uji heteroskedastisitas. (Priyatno, 2008) mengatakan bahwa, uji heteroskedastisitas digunakan untuk mengetahui ada atau tidaknya penyimpangan asumsi klasik heteroskedastisitas, yaitu adanya ketidaksamaan varian dari residual untuk pengamatan pada model regresi. Heteroskedastisitas adalah perubahan sistematis dalam penyebaran residu pada rentang nilai yang diukur. Heteroskedastisitas adalah masalah karena regresi kuadrat terkecil (OLS) mengasumsikan bahwa semua residu diambil dari populasi yang memiliki varian konstan (homoskedastisitas). Prasyarat yang harus dipenuhi dalam model regresi adalah tidak adanya gejala heteroskedastisitas.

Dalam penelitian ini, uji heteroskedastisitas dilakukan dengan Uji Breusch-PaganGodfrey, dimana dasar pengambilan keputusannya adalah dengan melihat nilai signifikansi. Jika nilai signifikansi lebih besar dari 0,05, maka tidak terjadi heteroskedastisitas, dan jika nilai signifikansi kurang dari 0,05, maka terjadi heteroskedastisitas. 
Tabel 2. Hasil Uji Heteroskedastisitas dengan Breusch-Pagan-Godfrey

Heteroskedasticity Test: Breusch-Pagan-Godfrey

\begin{tabular}{llll}
\hline \hline F-statistic & 10.12341 & Prob. F(3,60) & 0.0000 \\
Obs*R-squared & 21.50813 & Prob. Chi-Square(3) & 0.0001 \\
Scaled explained SS & 70.05130 & Prob. Chi-Square(3) & 0.0000 \\
\hline \hline
\end{tabular}

Test Equation:

Dependent Variable: RESID^2

Method: Least Squares

Date: 01/10/20 Time: 17:10

Sample: 164

Included observations: 64

\begin{tabular}{lrlll}
\hline \hline \multicolumn{1}{c}{ Variable } & Coefficient & Std. Error & t-Statistic & Prob. \\
\hline \hline C & -3899558. & 4494605. & -0.867609 & 0.3891 \\
DER & 1315865. & 4272587. & 0.307978 & 0.7592 \\
EPS & 7257.482 & 6050.754 & 1.199434 & 0.2351 \\
ROE & 349435.8 & 97586.95 & 3.580764 & 0.0721 \\
\hline \hline R-squared & 0.336064 & Mean dependent var & 7365065. \\
Adjusted R-squared & 0.302868 & S.D. dependent var & 20209095 \\
S.E. of regression & 16873472 & Akaike info criterion & 36.18085 \\
Sum squared resid & $1.71 E+16$ & Schwarz criterion & 36.31578 \\
Log likelihood & -1153.787 & Hannan-Quinn criter. & 36.23400 \\
F-statistic & 10.12341 & Durbin-Watson stat & 2.066692 \\
Prob(F-statistic) & 0.000017 & & & \\
\hline \hline
\end{tabular}

Sumber: (Output Eviews, 2020)

Dari hasil pengujian heteroskedastisitas yang tertuang dalam Tabel 2 dapat diketahui bahwa nilai Probabilitas (P Value) variable DER, EPS, dan ROE sebesar 0,759, 0,2351, dan 0,072. Nilai tersebut lebih besar dari 0,05 sehingga dapat disimpulkan bahwa tidak terjadi heteroskedastisitas pada variable-variabel tersebut.

Uji Autokorelasi. Selanjutnya, uji autokorelasi digunakan untuk mengetahui ada atau tidaknya penyimpangan asumsi klasik autokorelasi, yaitu korelasi yang terjadi antara residual pada satu pengamatan dengan pengamatan lain pada model regresi (Priyatno, 2008). Autokorelasi adalah korelasi (hubungan) yang terjadi antara anggota-anggota dari serangkaian pengamatan yang tersusun dalam rangkaian waktu atau yang tersusun dalam rangkaian ruang. Prasyarat yang harus terpenuhi adalah tidak adanya autokorelasi dalam model regresi. Untuk melakukan pengujian gejala autokorelasi dapat dilakukan dengan menggunakan uji Durbin Watson. 
Hasil Uji Durbin Watson adalah nilai Durbin Watson (DW) yang nantinya akan dibandingkan dengan dua (2) nilai Durbin Watson Tabel, yaitu Durbin Upper (DU) dan Durbin Lower DL). Sebuah penelitian dikatakan tidak mengandung autokorelasi apabila nilai DW lebih besar dari DU dan (4-DW) lebih besar dari DU atau bisa juga disebutkan dengan notasi sebagai berikut: $(4-\mathrm{DW})>\mathrm{DU}<\mathrm{DW}$.

Dari hasil pengujian autokorelasi yang tertuang dalam Tabel 2, diperoleh nilai DW sebesar 2,066. Sedangkan dari tabel DW dengan signifikansi 0,05. Karena DW terletak antara 1,9351 (dU) dan 2,0649 (4-dU), maka pada penelitian ini tidak terjadi atau tidak ada autokorelasi.

Koefisien Determinasi $\left(\mathbf{R}^{2}\right)$. Adjusted $\mathrm{R}$-squared digunakan sebagai koefisien determinasi dalam penelitian regresi yang menggunakan variabel bebas lebih dari dua.

Tabel 3. Hasil Regresi

Dependent Variable: HARGASAHAM

Method: Least Squares

Date: 01/10/20 Time: 16:24

Sample: 164

Included observations: 64

\begin{tabular}{lrlrl}
\hline \hline \multicolumn{1}{c}{ Variable } & Coefficient & Std. Error & t-Statistic & Prob. \\
\hline \hline C & -3387.263 & 746.6030 & -4.536900 & 0.0000 \\
DER & 837.5131 & 709.7233 & 1.180056 & 0.2426 \\
EPS & 16.28286 & 1.005096 & 16.20029 & 0.0000 \\
ROE & 219.5206 & 16.21026 & 13.54208 & 0.0000 \\
\hline \hline & & & \\
R-squared & 0.935354 & Mean dependent var & 7784.500 \\
Adjusted R-squared & 0.932121 & S.D. dependent var & 10758.12 \\
S.E. of regression & 2802.868 & Akaike info criterion & 18.77514 \\
Sum squared resid & $4.71 E+08$ & Schwarz criterion & 18.91007 \\
Log likelihood & -596.8043 & Hannan-Quinn criter. & 18.82829 \\
F-statistic & 289.3761 & Durbin-Watson stat & 1.632175 \\
Prob(F-statistic) & 0.000000 & & \\
\hline \hline
\end{tabular}

Sumber: (output Eviews, 2020)

Pada tabel diatas diketahui besarnya adjusted R-squared adalah 0,932. Semakin tinggi nilai $\mathrm{R}^{2}$ yang disesuaikan (adjusted $\mathrm{R}$-squared), akan semakin baik suatu model regresi karena variabel independen bisa menjelaskan variabel dependen lebih besar.

Dari tabel di atas menunjukkan bahwa DER, EPS, dan ROE (variabel independen) mampu menjelaskan 93,2\% harga saham (variabel dependen). Sedangkan sisanya, sebesar $6,8 \%$ dijelaskan oleh faktor-faktor atau variabel-variabel lain yang tidak dimasukkan sebagai variabel independen dalam penelitian ini. 
Korelasi Berganda. Untuk regresi dengan lebih dari dua variabel bebas, digunakan angka $\mathrm{R}$ untuk mengetahui hubungan antara dua varibel independen terhadap variabel dependen secara serentak. Berdasarkan pengujian yang ditampilkan dalam Tabel 2 diperoleh angka $\mathrm{R}$ sebesar 0,935. Menurut (Sugiyono, 2007) (Priyatno, 2008) koefisien korelasi antara 0,80 sampai dengan 1,00 menunjukkan hubungan yang sangat kuat. Sehingga 0,935 menunjukkan bahwa terjadi hubungan yang sangat kuat antara DER, EPS, dan ROE terhadap pergerakan harga saham.

Uji Regresi secara Parsial (Uji t). Uji t dikenal pula dengan nama uji parsial. Uji ini dilakukan untuk menguji apakah masing-masing variabel independen dalam sebuah penelitian memiliki pengaruh secara sendiri-sendiri terhadap variabel dependennya. Uji ini dilakukan dengan melakukan perbandingan antara t hitung dengan t tabel atau dengan melihat kolom signifikansi pada masing-masing $t$ hitung.

Tabel 4. Hasil Uji Regresi secara Parsial

\begin{tabular}{rlrl}
\hline & Model & T & Sig. \\
& & & \\
\hline & (Constant) & -4.536900 & 0.0000 \\
1 & DER & 1.180056 & 0.2426 \\
& EPS & 16.20029 & 0.0000 \\
& ROE & 13.54208 & 0.0000 \\
\hline
\end{tabular}

Sumber: (output Eviews, 2020)

H1: DER secara parsial memiliki pengaruh yang signifikan terhadap pergerakan harga saham

Berdasarkan Tabel 4 dapat dilihat bahwa tidak terdapat pengaruh DER terhadap pergerakan harga saham. Hal tersebut dibuktikan dengan hasil uji t dimana nilai signifikansinya lebih besar dari 5\%, yaitu sebesar 0,242. Dengan demikian, dapat disimpulkan bahwa $\mathrm{H} 1$ ditolak, yang berarti tidak terdapat pengaruh yang signifikan antara DER secara parsial terhadap pergerakan harga saham.

Hasil ini sesuai dengan penelitian yang dilakukan oleh (Husna, 2016) dan (Hudaya dan Pustikaningsih, 2017) yang menyatakan bahwa DER tidak memiliki pengaruh terhadap harga saham.

Hasil penelitian ini berbeda dengan penelitian yang telah dilakukan oleh (Haryanti dan Murtiasih, 2019), (Nahariyah dan Apriatni, 2017), (Ratih dkk., 2013), dan (Amanda, 2013) di mana hasil penelitiannya menunjukkan bahwa secara parsial DER mempunyai pengaruh terhadap harga saham. Hal tersebut dapat terjadi karena DER tidak mempengaruhi harga saham secara langsung tetapi melalui biaya modal dari hutang yang dikeluarkan apakah bisa diimbangi dengan pendapatan yang diperoleh dari penggunaan harta yang dibiayai oleh hutang tersebut. Sehingga besar pembiayaan yang diperoleh dari hutang tidak menjadi masalah jika perusahaan mampu membuat komposisi struktur modal optimal yang memberikan pendapatan lebih besar dibandingkan biaya modalnya sehingga pada akhirnya akan memberikan laba yang dapat memaksimalkan kesejahteraan pemegang saham yang ditandai dengan meningkatnya harga saham. Walaupun secara statistik DER tidak 
mempengaruhi harga saham tetapi investor sebaiknya tidak mengabaikannya karena DER masih menjadi salah satu rasio untuk mengukur kesehatan perusahaan.

\section{H2: EPS secara parsial memiliki pengaruh yang signifikan terhadap pergerakan harga} saham

Berdasarkan Tabel 4 dapat dilihat bahwa EPS secara parsial berpengaruh terhadap harga saham. Hal ini dibuktikan dengan nilai signifikasi EPS yang lebih kecil dari 5\%, yaitu sebesar 0,000. Artinya, H2 diterima. Hasil uji t terhadap variable EPS memperoleh nilai $\mathrm{t}$ hitung sebesar 16,200, dimana nilai t hitung ini lebih besar dari t table yang hanya sebesar 2,179. Hal ini menandakan bahwa pengaruh EPS secara parsial terhadap harga saham sangat signifikan. Hasil ini mendukung penelitian sebelumnya yang dilakukan oleh (Amanda, 2013), (Islam et al., 2014), (Ernest dan Oscar, 2014), (Inyiama, 2015), (Nahariyah dan Apriatni, 2017), (Kumar, 2017), (Widya dan Abundanti, 2018), dan (Haryanti dan Murtiasih, 2019) di mana hasil penelitiannya menunjukkan bahwa secara parsial EPS mempunyai pengaruh signifikan terhadap harga saham.

Untuk melihat kinerja perusahaan, salah satunya dapat dilihat pada nilai EPS. Semakin tinggi nilai EPS, maka semakin mahal suatu saham. Hal ini juga dibuktikan oleh

(Amanda, 2013) yang menyatakan bahwa investor tertarik dengan nilai EPS yang besar karena semakin tinggi nilai EPS, maka semakin meningkat pula harga saham sebuah perusahaan.

Semakin tinggi pendapatan per saham yang diterima oleh investor tentu akan menjadi daya tarik tersendiri sehingga semakin meningkatkan minat investor untuk membeli saham tersebut. Semakin saham tersebut banyak diminati, maka akan menaikkan harga saham.

H3: ROE secara parsial memiliki pengaruh yang signifikan terhadap pergerakan harga saham

Berdasarkan Tabel 4, dapat dilihat bahwa ROE secara parsial berpengaruh terhadap harga saham. Hal ini dibuktikan dengan nilai signifikasi EPS yang lebih kecil dari 5\%, yaitu sebesar 0,000. Artinya, H3 diterima. Hasil uji t terhadap variable ROE memperoleh nilai $t$ hitung sebesar 13,542, dimana nilai t hitung ini lebih besar dari t table yang hanya sebesar 2,179 . Hal ini menandakan bahwa pengaruh ROE secara parsial terhadap harga saham sangat signifikan. Hal ini menunjukkan bahwa investor menjadikan nilai ROE perusahaan dalam pertimbangan keputusan investasinya karena investor mempertimbangkan kemampuan perusahaan dalam mengoptimalkan ekuitasnya untuk menghasilkan laba. Hasil ini mendukung penelitian sebelumnya yang dilakukan oleh (Ratih dkk., 2013), (Issah dan Mohammed, 2015), (Nahariyah dan Apriatni, 2017), (Hudaya dan Pustikaningsih, 2017), (Widya dan Abundanti, 2018), dan (Christian dan Frecky, 2019), di mana hasil penelitiannya menunjukkan bahwa secara parsial ROE mempunyai pengaruh signifikan terhadap harga saham.

Hasil penelitian ini berbeda dengan hasil penelitian yang dilakukan oleh (Al Qaisi et al., 2016) yang menyebutkan bahwa ROE tidak memiliki pengaruh yang signifikan terhadap harga saham secara parsial. 


\section{Uji Regresi secara Bersama-sama (Uji F)}

\section{H4: DER, EPS, dan ROE secara simultan memiliki pengaruh yang signifikan terhadap pergerakan harga saham}

Uji $\mathrm{F}$ digunakan untuk mengetahui apakah variabel independen sebuah penelitian secara bersama-sama memiliki pengaruh yang signifikan terhadap variabel dependennya. Uji ini juga ditujukan untuk mengetahui apakah model regresi dapat digunakan untuk memprediksi variabel dependen atau tidak. Signifikan berarti hubungan yang terjadi dapat berlaku untuk populasi atau dapat digeneralisasikan. Uji ini dapat dilakukan dengan mambandingkan $\mathrm{F}$ hitung dengan $\mathrm{F}$ table.

Berdasarkan Tabel 3, diperoleh F hitung sebesar 289.3761. Dengan tingkat keyakinan, tingkat signifikansi $5 \%$, df $1=3$ serta df $2=12$, diperoleh nilai $F$ table sebesar 8,74. Karena nilai $\mathrm{F}$ hitung lebih besar daripada $\mathrm{F}$ table dan nilai signifikasi yang lebih kecil dari 0,05 , yaitu sebesar 0,000, maka dapat disimpulkan bahwa H4 diterima. Artinya, ada pengaruh yang signifikan antara DER, EPS, dan ROE secara bersama-sama terhadap harga saham. Hasil ini mendukung penelitian sebelumnya yang dilakukan oleh Amanda, 2013) dan Nahariyah dan Apriatni (2017), di mana hasil penelitiannya menunjukkan bahwa secara simultan DER, EPS, dan ROE mempunyai pengaruh yang signifikan terhadap harga saham.

\section{KESIMPULAN}

Berdasarkan hasil pengujian dalam penelitian ini, diperoleh hasil: (1) Secara parsial, DER tidak memiliki pengaruh yang signifikan terhadap pergerakan harga saham perusahaan yang terdaftar dalam JII pada tahun 2014-2017. (2) Secara parsial, EPS dan ROE memiliki pengaruh yang signifikan terhadap pergerakan harga saham perusahaan yang terdaftar dalam JII pada tahun 2014-2017. (3) Secara simultan, DER, EPS, dan ROE memiliki pengaruh yang signifikan terhadap pergerakan harga saham perusahaan yang terdaftar dalam JII pada tahun 2014-2017.

Saran. Bagi investor hasil penelitian ini bisa dijadikan pertimbangan dalam berinvestasi pada saham. Saham yang akan dipilih sebaiknya dari emiten yang menunjukkan kinerja yang baik ditandai dengan nilai EPS dan ROE positif yang menggambarkan potensi return dan laba yang akan diperoleh perusahaan di masa sekarang dan yang akan datang. Sedangkan variabel DER meskipun tidak mempengaruhi secara parsial harga saham dalam penelitian ini, tetapi tidak bisa diabaikan karena DER masih menjadi salah satu rasio untuk mengukur kesehatan perusahaan.

Beberapa saran atau rekomendasi yang dapat diberikan sehubungan dengan hasil penelitian ini untuk penelitian selanjutnya adalah sebagai berikut: (1) Variabel yang digunakan dalam penelitian ini hanya ada tiga variabel independen yang mempengaruhi harga saham, yaitu DER, EPS, dan ROE. Diharapkan penelitian selanjutnya menambah dengan variabel yang lebih banyak lagi dengan tidak mengabaikan kondisi-kondisi yang sedang berlangsung, seperti mempertimbangkan pengendalian faktor ekonomi, politik dan faktor-faktor lain diluar model penelitian ini yang mempengaruhi harga saham di Bursa Efek untuk perluasan penelitian. (2) Keterbatasan dalam penelitian ini adalah sampel yang digunakan dalam penelitian hanya mendasarkan pada perusahaan yang terdaftar di JII. 
Penelitian berikutnya perlu memperhatikan penggunaan sampel dari perusahaan yang terdaftar dalam Indeks Saham Syariah Indonesia (ISSI) di Bursa Efek Indonesia agar dapat lebih mewakili pasar secara keseluruhan. (3) Waktu pengamatan penelitian yang digunakan hanya dalam empat tahun dari tahun 2014 sampai dengan tahun 2017. Sebaiknya waktu yang digunakan selanjutnya lebih panjang dan lebih baru lagi karena dapat digunakan oleh investor dalam menilai harga saham pada saat sekarang ini.

\section{DAFTAR PUSTAKA}

Al Qaisi, Fouzan dan Asem Tahtamouni dan Mustafa A.A. AL-Qudah. (2016). Factors Affecting the Market Stock Price - The Case of the Insurance Companies Listed in Amman Stock Exchange. International Journal of Business and Social Science. Vol. 7, No. 10.

Amanda (2013). Pengaruh Debt to Equity Ratio, Return on Equity, Earning Per Share, dan Price Earning Ratio terhadap Harga Saham (Studi pada Perusahaan Food and Beverages yang Terdaftar di BEI Tahun 2008-2011. Jurnal Administrasi Bisnis Universitas Brawijaya. Vol. 4, No. 2.

Antono, Zakia Maulida dan Adam Amril Jaharadak dan Abdul Ali Khatibi. (2019). Analysis of Factors Affecting Stock Prices in Mining Sector: Evidence from Indonesia Stock Exchange. Management Science Letters. 9 (2019), 1701-1710.

Christian, Natalis dan Frecky. (2019). Analisis Pengaruh Faktor-Faktor Yang Mempengaruhi Harga Saham pada Perusahaan yang Terdapat di Bursa Efek Indonesia. Jurnal Benefita, Vol. 4, No. 1, pp: 115-136.

Darsono dan Ashari. (2005). Pedoman Praktis Memahami Laporan Keuangan Edisi 1). Yogyakarta: ANDI.

Ernest, O., and Oscar, M. C. (2014). The Comparative Study of Value Relevance of Financial Information in The Nigeria Banking and Petroleum Sectors. Journal of Business Studies Quarterly, 6(1).

Haryanti, Yuli dan Sri Murtiasih. (2019). The Effects of DER, ROA and DPR on Stock Price with EPS as the Moderating Variable in SOE. IOSR Journal of Business and Management. Volume 21, Issue 7.

Hasan, Iqbal. (2008). Analisis Data Penelitian dengan Statistik. Jakarta: Bumi Aksara.

Hudaya, Fendi Ramadhani dan Adeng Pustikaningsih. (2017). Pengaruh Debt to Equity Ratio (DER), Return On Equity (ROE) dan Net Profit Margin (NPM) terhadap Harga Saham Perusahaan Sektor Pertambangan yang Terdaftar di Bursa Efek Indonesia Periode 2011-2015. Jurnal Profita, Vol. 8, No. 1.

Husna, Nailal. (2016). Analisis Pengaruh pada Kinerja Keuangan terhadap Harga Saham pada Perusahaan Perbankan. e-Jurnal Apresiasi Ekonomi, Vol. 4, No. 2, pp: 151-156.

Inyiama, O. I. (2015). Does Eaning Per Share Determine Market Price of Ordinary Share? Evidence from Nigeria Banking Sector (2000-2013). European Journal of Accounting Auditing and Finance Research, Vol.3, No.6, pp: 91-102.

Islam, Rashidul dan Tahsan Rahman Khan dan Tonmoy Toufic Choudhury dan Ashique Mahmood Adnan. (2014). How Earning Per Share (EPS) Affects on Share Price and Firm Value. European Journal of Business and Management. Vol.6, No.17.

Issah, Osman dan Iddrisu Mohammed Ngmenipuo. (2015). An Empirical Study of The Relationship between Profitability Ratios and Market Share Prices of Publicly Traded 
Banking Financial Institutions in Ghana. International Journal of Economics, Commerce and Management. Vol. III, Issue 12.

Kumar, P. (2017). Impact of Earning Per Share and Price Earning Ratio on Market of Share: A Study on Auto Sector in India. International Journal of Research-Granthaalayah, Vol. 5, No.2, pp: 113-118.

Nahariyah, Rohmatun dan Apriatni E.P. (2017). Pengaruh Current Ratio (CR), Debt to Equity Ratio (DER), Return on Asset (ROA), Return on Equity (ROE), dan Earning Per Share (EPS) terhadap Harga Saham pada Perusahaan Sub Sektor Konstruksi Bangunan yang Terdaftar di Bursa Efek Indonesia Periode 2011-2015. Jurnal Ilmu Administrasi Bisnis Universitas Diponegoro. Volume 6, Nomor 4.

Priyatno, Duwi. (2008). Mandiri Belajar SPSS. Yogyakarta: Mediakom.

Ratih, Dorothea dan Apriatni E.P. dan Saryadi. (2013). Pengaruh EPS, PER, DER, ROE terhadap Harga Saham pada Perusahaan Sektor Pertambangan yang Terdaftar di Bursa Efek Indonesia (BEI) Tahun 2010-2012. Diponegoro Journal of Social and Politic: Hal. 1-12.

Rauf, A. L. A. (2015). What Determine Share Price? Evidence from Banking Sector Listed in Colombo Stock Exchange. 5th International Symposium 2015, 29-31.

Samsul, Mohamad. (2011). Pasar Modal \& Manajemen Portofolio. Jakarta: Erlangga.

Sugiyono. (2010). Metode Penelitian Bisnis. Bandung: Alfabeta.

Wahyu, Wing Winarno. (2009). Analisis Ekonometrika dan Statistika dengan EViews (4th ed.). Yogyakarta: UPP STIM YKPN.

Widya, Pande Rahmadewi dan Nyoman Abundanti. (2018). Pengaruh EPS, PER, CR, dan ROE terhadap Harga Saham di Bursa Efek Indonesia. E-Jurnal Manajemen Unud, Vol. 7, No. 4.

www.idx.co.id 